\title{
Study and Application of Deep Profile Control and Oil Displacement Technology in the Fractured Tight Oil Reservoir
}

\author{
Lei Zhang ${ }^{1,2, a}{ }^{*}$, Chunsheng $\mathrm{Pu}^{1,2, \mathrm{~b}}$, Liming Zheng ${ }^{1,2, \mathrm{c}}$ and Xiaoyu $\mathrm{Gu}^{1,2, \mathrm{~d}}$ \\ ( ${ }^{1}$ Institute of Petroleum Engineering and ${ }^{2}$ Research Center of Physical-Chemical Engineering and \\ Technology on the Development of Complex Reservoirs, China University of Petroleum (East \\ China), Qingdao 266580, China) \\ aemail: zhangshishishi.188@163.com, bemail: chshpu@163.com, 'email: 1165107079@qq.com, \\ demail: 458570670@qq.com
}

Keywords: profile control and oil displacement; fractured tight oil reservoir; copolymer; multistage alternating injection; increasing oil and decreasing water cut

Abstract: In order to plug water channeling of fractured tight oil reservoir, a new type of copolymer as the main agent is used for deep profile control and oil displacement. This copolymer is synthesized with modified cellulose and acrylamide, which has relatively lower viscosity and can meet the requirements of injection into the formation. And it has good performance of shear resistance, which can migrate into the deep formation and maintain the good performance. And a gel, which is consisting of the copolymer and cross-linking agent, has a good performance under formation conditions. The gel strength and gelation time can be controlled to meet the requirements of construction. Oilfield construction shows that the way of multistage alternating injection of the profile control and oil displacement agent and formation water can push the gel into the deep formation and can plug the water channeling of fractures to improve the sweep efficiency with a wider range. After construction, the oil production is increased from $1.13 \mathrm{t} / \mathrm{d}$ to $4 \mathrm{t} / \mathrm{d}$ and the water cut is decreased from $98.16 \%$ to $91.54 \%$. The results of laboratory experiment and field test show that the developed profile control and oil displacement agent and the way of multistage alternating injection are suitable for EOR of the fractured tight oil reservoirs.

\section{Introduction}

Technology of profile control and water shutoff is the most powerful guarantee to stabilize oil production and control water cut ${ }^{[1-5]}$. In order to further improve the success rate of this technology, a new type of profile control and oil displacement agent and new technological method are always the research target of petroleum engineers and scientists. Water channeling passage in the fractured tight reservoir is different scales of fractures. The goal of profile control and oil displacement is to plug these fractures to expand swept volume. So it requires that the initial viscosity of the profile control and oil displacement agent is low, and its gel strength and cross-linking time is controllable. Based on this, a new type of graft copolymer, which is synthesized with modified cellulose and acrylamide, is used as the main agent of profile control and oil displacement agent ${ }^{[6-9]}$. In this paper, its adaptability for the profile control and water plugging is discussed. Besides, during the construction process, the profile control and oil displacement agent needed to be pushed into the deep formation as much as possible to expand the swept volume in a wider range. So the multistage alternating injection of the in-depth profile control and oil displacement agent and formation water is used as the construction way in the field experiment. 


\section{Experiments}

Experiment instruments and reagents. Graft copolymer of superfine cellulose and acrylamide is white solid and is developed by the laboratory. And the experiment method can be queried in the seventh references ${ }^{[7]}$. Organic crosslinking agent is also developed by the laboratory, which is consisting of methenamine and hydroxyphenol according to certain proportion. Control agent is ammonium chloride, which is provided by Sinopharm. The salinity of simulated formation water is $30000 \mathrm{mg} / \mathrm{L}$, which contains $3000 \mathrm{mg} / \mathrm{L} \mathrm{CaCl} 2,1000 \mathrm{mg} / \mathrm{L} \mathrm{MgCl}_{2}, 26000 \mathrm{mg} / \mathrm{L} \mathrm{NaCl}$. The composition of the simulated formation water is in accordance with the produced water from Yangchang oilfield. Brookfield viscometer is from Brookfield Company.

Experiment method. The profile control and oil displacement agent is prepared with the simulated formation water. The properties of the profile control and oil displacement agent is observed and tested by adjusting the concentration of the polymers, cross-linking agent or control agent under $50^{\circ} \mathrm{C}$. And its shear-resistant property is studied under the high speed shearing of $100 \mathrm{~S}^{-1}$. The goal is to select a suitable formula for the fractured tight oil reservoirs. The shear rate is 7.34 $\mathrm{S}^{-1}$.

\section{Results and discussion}

Influence of copolymer concentration on the gel properties. The result of the influence of polymer concentration on the gel performance is shown in Fig. 1. From Fig. 1, it can be seen that when the copolymer concentration is less than $2000 \mathrm{mg} / \mathrm{L}$, the gel strength is greatly increasing with the increase of polymer concentration. However, when the polymer concentration is greater than $2000 \mathrm{mg} / \mathrm{L}$, the increase of gel strength with the increasing of copolymer concentration becomes slow. In the range of low concentration, the cross-linking points increase with the increase of copolymer concentration, so that the gel strength increases. When the polymer concentration increases to $2000 \mathrm{mg} / \mathrm{L}$, the cross-linking points have tended to be saturated. So increasing copolymer concentration cannot significantly increase the gel strength. And the initial viscosity of the copolymer solution is low, which can be observed from the relationship curve of the viscosity of copolymer solution and the concentration shown in Fig. 1. The viscosity of the copolymer solution with $2000 \mathrm{mg} / \mathrm{L}$ is $30 \mathrm{mPa}$.s, which can meet the requirements of injection into the formation.

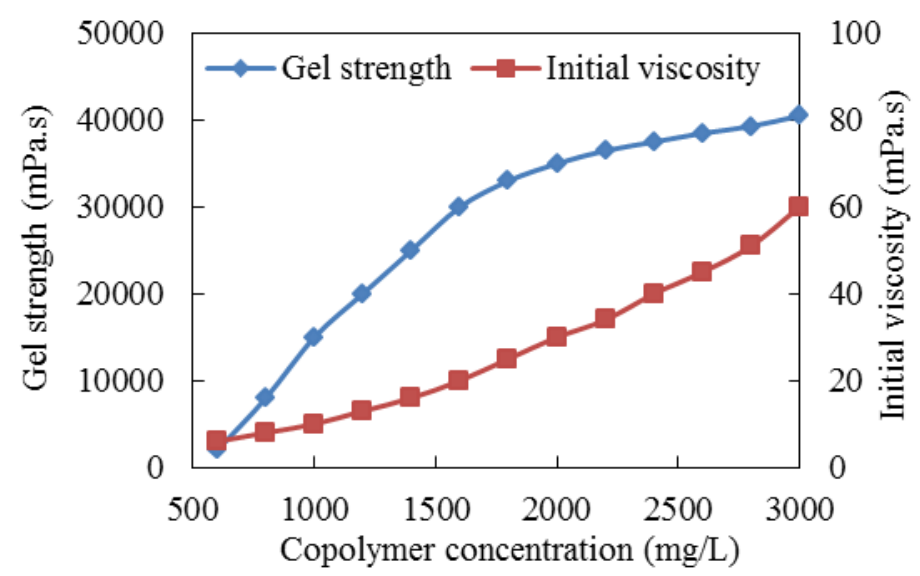

Fig. 1 Influence of copolymer concentration on the gel properties (Cross-linking agent concentration is $1000 \mathrm{mg} / \mathrm{L}$ and control agent concentration is $20 \mathrm{mg} / \mathrm{L}$.)

Influence of cross-linking agent concentration on the gel properties. The result of the 
influence of crosslinking agent concentration on the gel properties is shown in Fig. 2. In Fig. 2, it can be seen that $1000 \mathrm{mg} / \mathrm{L}$ of the cross-linking agent concentration can be used as the demarcation point. When the concentration is less than the point, the gel strength is greatly increasing with the increasing of crosslinking agent concentration. When the concentration is more than the point, the increase of gel strength with the increasing of crosslinking agent concentration becomes slow. Besides, from the relationship curve of the crosslinking agent concentration and gelation time shown in Fig. 2, it can be seen that the gelation time becomes shorter when the cross-linking agent concentration is increasing. It is not good for plugging the channeling-path in the formation when the gelation time is too short or too long. By comparison of the gel strength curve and the gelation time curve, the optimal concentration of cross-linking agent is $1000 \mathrm{mg} / \mathrm{L}$.

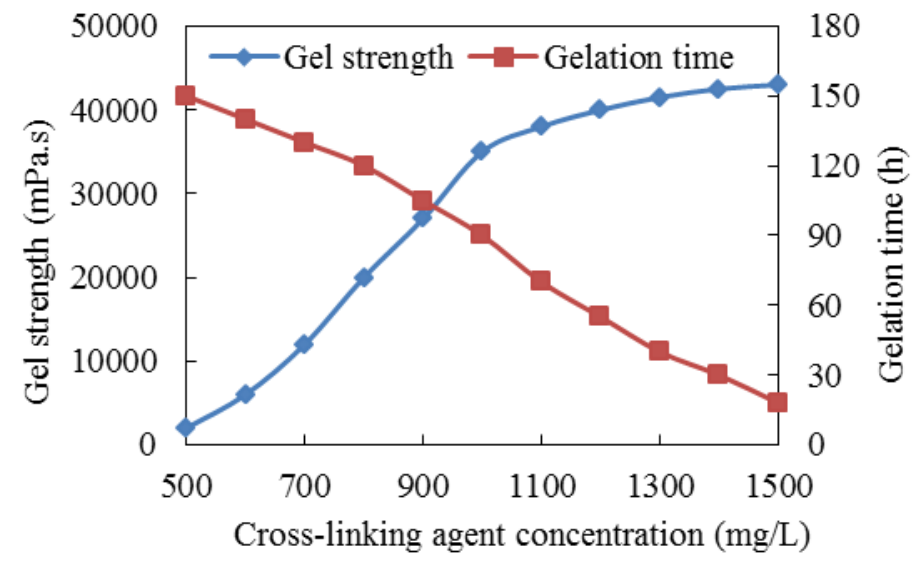

Fig. 2 Influence of cross-linking agent concentration on the gel properties (copolymers concentration is $2000 \mathrm{mg} / \mathrm{L}$ and control agent concentration is $20 \mathrm{mg} / \mathrm{L}$.)

Influence of control agent concentration on the gel properties. The result of the influence of control agent concentration on the gel properties is shown in Fig. 3. From Fig. 3, it can be seen that increasing the control agent concentration can improve the gel strength and shorten the gelation time in a certain concentration range. When the control agent concentration is $20 \mathrm{mg} / \mathrm{L}$, gel strength and gelation time are the most appropriate for the deep profile control and oil displacement.

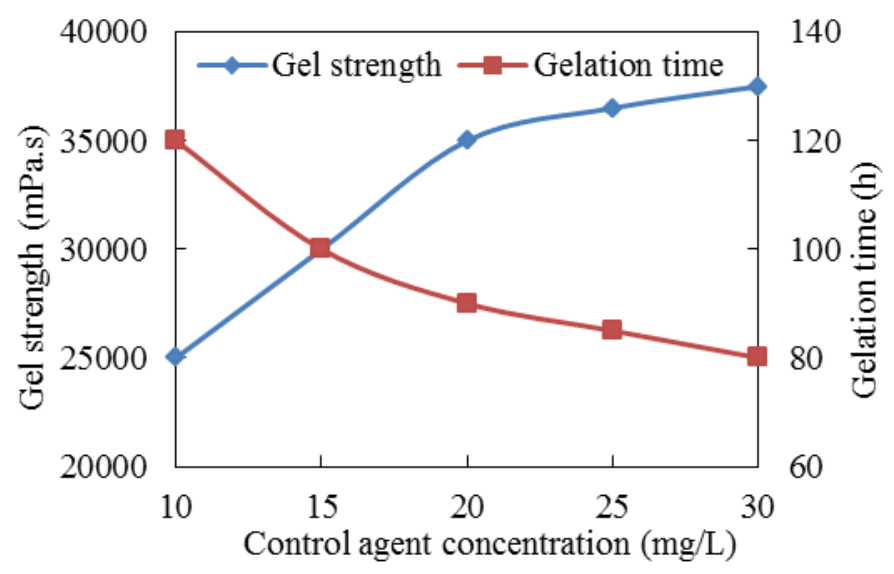

Fig. 3 Influence of control agent concentration on the gel properties (copolymers concentration is $2000 \mathrm{mg} / \mathrm{L}$ and cross-linking agent concentration is $20 \mathrm{mg} / \mathrm{L}$.)

Characteristics of shearing resistance. The profile control and oil displacement agent is 
prepared with the simulated formation water, which is consisting of $2000 \mathrm{mg} / \mathrm{L}$ copolymer, 1000 $\mathrm{mg} / \mathrm{L}$ cross-linking agent and $20 \mathrm{mg} / \mathrm{L}$ control agent. Then the profile control and oil displacement agent is sheared under $100 \mathrm{~S}^{-1}$ of shear rate. The result of anti-shear ability of the profile control and oil displacement agent is shown in Fig. 4. From Fig. 4, it can be seen that the initial viscosity of the solution is decreasing with the increase of shear time. But the viscosity retention rate is still more than $60 \%$. After shearing, the gel strength is decreased, but its viscosity is still higher than 26000 mPa.s. The viscosity retention ratio is more than $80 \%$ and the stable stage is more than $180 \mathrm{~d}$. These indicate that the profile control and oil displacement agent has strong resistance to shear.

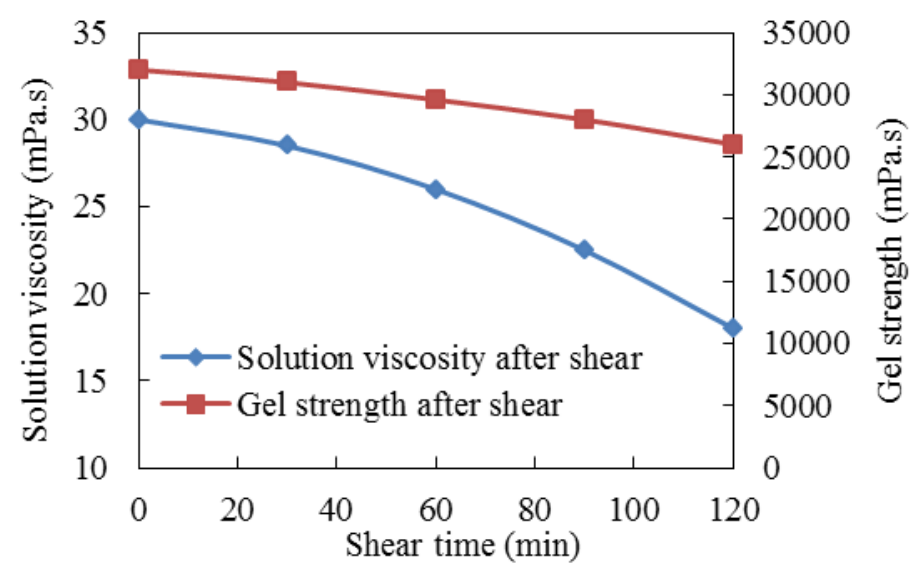

Fig. 4 Influence of shear on the gel properties

\section{Field application of the deep profile control and oil displacement technology}

Well area overview. Injection well of S8-6 is in located in the Western of Shuanghe oilfield in Yongning Production Plant which is a subsidiary of Yangchang Oilfield Group Co., LTD. The main oil-bearing layer is Chang $6_{2}$ reservoir. The variable coefficient is 0.92 and the permeability max-mean ratio is 2.30. It is a typical fractured tight oil reservoir with strong heterogeneity and fracture development. The oilfield is developed by advancing water flooding in 2007 . The well pattern is $120 \mathrm{~m} \times 240 \mathrm{~m}$. The water cut is $70 \%$ at the beginning of the production. The oilfield enters into the stage of high water cut in 2011. At present, the water injection volume is $15 \mathrm{~m}^{3}$ per day when the injection pressure is $4 \mathrm{MPa}$. The basic data of the injection well of S8-6 and oil wells is shown in Table 1 and Table 2, respectively.

Table 1 Basic data of the water injection well of S8-6

\begin{tabular}{ccccccc}
\hline Layer & $\begin{array}{c}\text { Perforation } \\
\text { interval }(\mathrm{m}-\mathrm{m})\end{array}$ & $\begin{array}{c}\text { sand layer } \\
\text { thickness } \\
(\mathrm{m})\end{array}$ & $\begin{array}{c}\text { Porosity } \\
(\%)\end{array}$ & $\begin{array}{c}\text { Permeability } \\
\left(\times 10^{-3} \mu \mathrm{m}^{2}\right)\end{array}$ & $\begin{array}{c}\text { oil } \\
\text { saturation } \\
(\%)\end{array}$ & $\begin{array}{c}\text { Interpretation } \\
\text { results }\end{array}$ \\
\hline $\begin{array}{c}\text { Chang } \\
6_{2}\end{array}$ & $\begin{array}{c}1583.9-1586 . \\
5\end{array}$ & 2.6 & 14.8 & 3.3 & 62.7 & oil reservoir \\
$\begin{array}{c}\text { Chang } \\
6_{2}\end{array}$ & $\begin{array}{c}1590.7-1593 . \\
2\end{array}$ & 2.5 & 11.5 & 1.0 & 54.6 & oil reservoir \\
\hline
\end{tabular}


Table 2 Basic data of the corresponding oil wells

\begin{tabular}{cccccc}
\hline $\begin{array}{c}\text { Oil } \\
\text { well }\end{array}$ & Layer & $\begin{array}{c}\text { Perforation interval } \\
(\mathrm{m}-\mathrm{m})\end{array}$ & $\begin{array}{c}\text { sand layer } \\
\text { thickness }(\mathrm{m})\end{array}$ & $\begin{array}{c}\text { Production } \\
\text { time }\end{array}$ & $\begin{array}{c}\text { Artificial } \\
\text { bottom }(\mathrm{m})\end{array}$ \\
\hline S7-5 & Chang 62 & $1538.7-1557.7$ & 7.4 & 2007.06 & 1650 \\
S7-6 & Chang 62 & $1577.6-1580.4$ & 9 & 2008.10 & 1640 \\
S7-7 & Chang 6 & $1560.2-1593.6$ & 10.7 & 2007.05 & 1686 \\
S9-5 & Chang 62 & $1538.9-1541.5$ & 5 & 2007.07 & 1662 \\
S9-6 & Chang 6 & $1574.7-1582.3$ & 14.2 & 2008.11 & 1624 \\
S9-7 & Chang 6 & $1579.1-1582.7$ & 6.7 & 2007.08 & 1647 \\
\hline
\end{tabular}

Construction design of deep profile control and oil displacement. The first problem of construction of deep profile control and oil displacement in the fractured tight reservoir is poor injectability. Even though the initial viscosity of the deep profile control and oil displacement agent is very low, only low injection rate can meet the construction requirements. During the construction process, the multistage alternating injection of the in-depth profile control and oil displacement agent and formation water is used to ensure that the profile control and oil displacement agent can migrate into the deep formation and can prevent keeping down pressure near the bottom. The main construction parameters of profile control and oil displacement is shown in Table 3.

Table 3 Main construction parameters of profile control and oil displacement

\begin{tabular}{|c|c|c|c|}
\hline $\begin{array}{c}\text { serial } \\
\text { number }\end{array}$ & $\begin{array}{l}\text { construction } \\
\text { parameters }\end{array}$ & Detailed indicators & Operating purposes \\
\hline 1 & injection mode & General injection & $\begin{array}{c}\text { It is consistent with water injection mode, which } \\
\text { doesn't need to change the tubing string } \\
\text { structure. }\end{array}$ \\
\hline 2 & $\begin{array}{l}\text { construction } \\
\text { method }\end{array}$ & $\begin{array}{l}\text { multistage } \\
\text { alternating injection } \\
\text { of agent and water }\end{array}$ & $\begin{array}{l}\text { It can make the agent migrate into the deep } \\
\text { formation and prevent keeping down pressure } \\
\text { near the bottom. }\end{array}$ \\
\hline 3 & $\begin{array}{l}\text { copolymer } \\
\text { concentration }\end{array}$ & $2000 \mathrm{mg} / \mathrm{L}$ & $\begin{array}{l}\text { It can ensure that the initial viscosity of the } \\
\text { agent is low and has a certain degree of strength } \\
\text { after gelation. }\end{array}$ \\
\hline 4 & injection rate & $<1 \mathrm{~m}^{3} / \mathrm{h}$ & $\begin{array}{l}\text { Low injection rate can make more of the agent } \\
\text { migrate into large channeling-path duo to low } \\
\text { injection pressure. }\end{array}$ \\
\hline 5 & $\begin{array}{l}\text { injection } \\
\text { pressure }\end{array}$ & $<12 \mathrm{MPa}$ & $\begin{array}{l}\text { It can prevent fracturing the formation and } \\
\text { damaging the string. }\end{array}$ \\
\hline
\end{tabular}

Design goal is that the injection volume can reach $20 \mathrm{~m}^{3} / \mathrm{d}$ and the injection pressure is lower than $12 \mathrm{MPa}$ after construction. The construction is operated according to the designed parameters which are shown in Table 3. The construction curve of injection well of S8-6 is shown in Fig. 5. The profile control and oil displacement agent used in the construction is consisting of $2000 \mathrm{mg} / \mathrm{L}$ copolymer, $1000 \mathrm{mg} / \mathrm{L}$ cross-linking agent and $20 \mathrm{mg} / \mathrm{L}$ control agent, and its cumulative injection volume is $705 \mathrm{~m}^{3} .1 .41$ tons of the copolymer powder and 0.705 tons of the cross-linking agent are used. From Fig. 5, it can be seen that the injection pressure is slowly increasing by a stepwise way. It suggests that the multistage alternating injection of agent and water can make the pressure around 
the wellbore gradually propagate into the deep formation, which can push the profile control and oil displacement agent into the deep formation to avoid the accumulation and pressure-out in the near wellbore zone. After construction, the injection volume is $20 \mathrm{~m}^{3} / \mathrm{d}$ and the injection pressure is 10.1 $\mathrm{MPa}$, which can meet the requirement of the planned injection pressure and injection allocation.

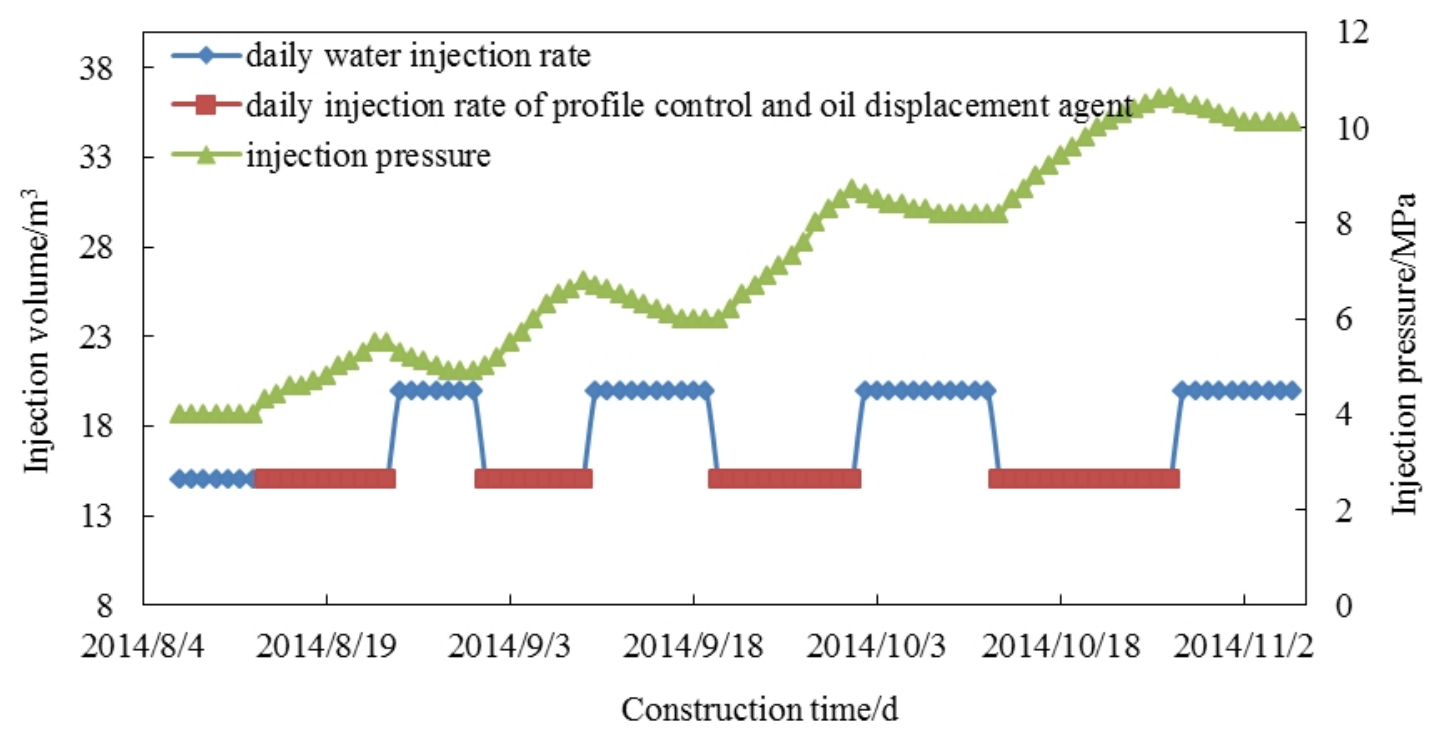

Fig. 5 Construction curve of multistage alternating injection of S8-6 water injection well

Analysis of construction effect. Production status of the corresponding oil well of S8-6 water injection well before and after construction is shown in Table 4. From Table 4, it can be seen that shows that the oil production is obviously improved and the water cut is significantly reduced after construction of deep profile control and oil displacement. The increment of oil production of the well group is 2.87 tons per day and the water cut is decreased from $98.16 \%$ to $91.54 \%$. The valid date is more than $180 \mathrm{~d}$. It shows that the way of multistage alternating injection can produce a better construction effect of profile control and oil displacement.

Table 4 Production status of the corresponding oil well of S8-6 water injection well

\begin{tabular}{cccccccc}
\hline & \multicolumn{3}{c}{$\begin{array}{c}\text { Production status before } \\
\text { construction }\end{array}$} & \multicolumn{3}{c}{ Production status after construction } & Oil \\
\cline { 2 - 6 } number & $\begin{array}{c}\text { Daily fluid } \\
\text { output } \\
\left(\mathrm{m}^{3} / \mathrm{d}\right)\end{array}$ & $\begin{array}{c}\text { Daily oil } \\
\text { output } \\
(\mathrm{t} / \mathrm{d})\end{array}$ & $\begin{array}{c}\text { Water } \\
\text { cut }(\%)\end{array}$ & $\begin{array}{c}\text { Daily fluid } \\
\text { output } \\
\left(\mathrm{m}^{3} / \mathrm{d}\right)\end{array}$ & $\begin{array}{c}\text { Daily oil } \\
\text { output } \\
(\mathrm{t} / \mathrm{d})\end{array}$ & $\begin{array}{c}\text { Water } \\
\text { cut }(\%)\end{array}$ & $\begin{array}{c}\text { increment } \\
(\mathrm{t} / \mathrm{d})\end{array}$ \\
\hline S7-5 & 12.2 & 0.12 & 99.02 & 10.2 & 0.7 & 93.14 & 0.58 \\
S7-6 & 1.5 & 0.15 & 90.00 & 1.5 & 0.3 & 80 & 0.15 \\
S7-7 & 20.6 & 0.2 & 99.03 & 13.3 & 0.9 & 93.23 & 0.7 \\
S9-5 & 3.71 & 0.19 & 94.88 & 3.4 & 0.6 & 82.35 & 0.41 \\
S9-6 & 7.4 & 0.15 & 97.97 & 6.4 & 0.6 & 90.63 & 0.45 \\
S9-7 & 16 & 0.32 & 98.00 & 12.5 & 0.9 & 92.8 & 0.58 \\
\hline
\end{tabular}




\section{Conclusions}

(1) A kind of graft copolymer of modified cellulose and AM is systematically studied as the main agent for the profile control and oil displacement. The deep profile control and oil displacement agent, which is developed by the copolymer and cross-linking agent, has low initial viscosity and good resistance to shear. It can migrate into the deep formation and maintain a stable performance. The cross-linking time and gel strength is controllable, which can meet the requirement of plugging water channeling.

(2) Field test shows that the way of multistage alternating injection of the in-depth profile control and oil displacement agent and formation water can push the gel into the deep formation and can plug the water channeling of fractures to improve the sweep efficiency with a wider range. That is to say that the developed profile control and oil displacement agent and the way of multistage alternating injection are suitable for EOR of the fractured tight oil reservoirs.

\section{Acknowledgments}

This study was supported by the Major National Science and Technology Projects (20011ZX05009-004) and the National Natural Science Fund (51274229).

\section{References}

[1] Y. Liu, B. Bai, Y. Wang, Applied technologies and prospects of conformance control treatments in China. Oil \& Gas Sci. Technol. 65 (2010) 859-878.

[2] C. L. Dai, Q. You, F. L. Zhao, In-depth profile control technologies in China-a review of the state of the art. Pet. Sci. Technol. 28 (2010) 1307-1315.

[3] X. F. Tang, Y. Z. Liu, L. M. Yang, et al. Laboratory researches on deep fluid diversion agent with high intensity and retarding swelling characteristics. Pet. Explor. Dev. 36 (2009) 494-497.

[4] D. K. Han, Discussions on concepts, countermeasures and technical routes for the redevelopment of high water-cut oilfields. Pet. Explor. Dev. 37 (2010) 583-591.

[5] X. J. Chang, X. J. Liu, Q. Y. Wang, et al. Researches on the PAM/Cr ${ }^{3+}$ gel for deep profile control. Pet. Sci. 1 (2004) 65-69.

[6] Y. Liao, S. Wang, Z. Luo, et al. Research on cellulose pyrolysis kinetics. Journal of Zhejiang University (Engineering Science) 36 (2002) 172-176. (in Chinese)

[7] S. H. Pan, R. Song, M. Zeng, Preparation of superabsorbent by grafted copolymerization of acrylic acid onto superfine cellulose. J. Cellulose Sci. Technol. 7 (1999) 24-27.

[8] V. Thakur, M. Thakur, R. Gupta, Graft copolymers from cellulose: synthesis, characterization and evaluation. Carbohyd. Polym. 97 (2013) 18-25.

[9] M. Peltzer, A. Pei, Q. Zhou, et al. Surface modification of cellulose nanocrystals by grafting with poly (lactic acid). Polym. Int. 63 (2014) 1056-1062. 